\title{
THE EFFECT OF SPECIMEN DIMENSIONS ON THE FLEXURAL STRENGTH OF A COMPOSITE RESIN
}

\author{
EFEITO DAS DIMENSÕES DO ESPÉCIME NA RESISTÊNCIA À FLEXÃO \\ DE UMA RESINA COMPOSTA
}

Antonio MUENCH ${ }^{1}$, Ivo Carlos CORREA², Rosa Helena Miranda GRANDE³, Mário JOÃO ${ }^{4}$

1- DDS, PhD, Professor, Department of Dental Materials, University of São Paulo.

2- DDS, MSc, PhD, Assistant Professor, Department of Restorative Dentistry, University Gama Filho.

3- DDS, MS, PhD, Associate Professor, Department of Dental Materials, University of São Paulo.

4- DDS, PhD Professor, Department of Restorative Dentistry, University Gama Filho.

Corresponding address: Profa. Dra. Rosa Helena Miranda Grande - Departamento de Materiais Dentários - Faculdade de Odontologia da USP Av. Prof. Lineu Prestes, 2227 - Cidade Universitária - Cep.: 05508-900 - São Paulo, SP, Brazil - Fone/Fax: (11) 3091-7840 - (11) 3091-7842 e-mail: grande@usp.br

Received: September 27, 2004 - Modification: April 11, 2005 - Accepted: April 25, 2005

\begin{abstract}
D

urpose: The aim of this study was to evaluate the effect of specimen dimensions on the flexural strength of a composite resin (Heliomolar RO). Methods: The different dimensions tested - length $\mathrm{x}$ width $\mathrm{x}$ height (mm) were: 25x2x4; 25x2x2 (ISO 4049); 15x2x2; 10x2x2 and 10x2x1. Light-curing was performed at $600 \mathrm{~mW} / \mathrm{cm}^{2}$ for 40 s, three times along the $25 \mathrm{~mm}$ specimens, twice along $15 \mathrm{~mm}$ specimen and once for the $10 \mathrm{~mm}$ specimens. Specimens of all dimensions were light-cured on both surfaces, or only on one side. In the latter, the load was applied on the irradiated side or on the opposite one. Results: It was shown that the flexural strength was not affected by specimen length. When light-curing was performed on both surfaces, similar flexural strength values were obtained for any dimension. Despite the number of irradiated surfaces, specimens with a height of $1 \mathrm{~mm}$ also obtained similar values. On the contrary, specimens with a height of $4 \mathrm{~mm}$, exposed only on one surface, reached the lowest strength. Conclusion: The use of specimens with lower dimensions can lead to flexural strength values similar to the ones obtained with standardized specimen (ISO 4049), with the advantage of demanding less amount of material and being less time consuming.
\end{abstract}

Uniterms: Composite resins; Flexural strength; Specimen dimensions.

\begin{abstract}
RESUMO
bjetivo: A finalidade da presente investigação foi avaliar a influência das dimensões dos corpos-de-prova (cp) e da superfície de irradiação na resistência à flexão de uma resina composta (Heliomolar RO). Métodos: As diversas dimensões adotadas - comprimento x largura x altura (mm) foram: 25x2x4; 25x2x2 (ISO 4049); 15x2x2; 10x2x2; 10x2x1. A fotoativação foi realizada por 40 segundos a $600 \mathrm{~mW} / \mathrm{cm}^{2}$; três vezes ao longo dos cp de $25 \mathrm{~mm}$, duas vezes ao longo dos cp de $15 \mathrm{~mm}$ e uma vez nos cp de $10 \mathrm{~mm}$ de comprimento. Os corpos-de-prova de todas as dimensões foram ativados em ambas as superfícies, ou apenas em uma; neste caso a carga de ruptura era aplicada na face de irradiação ou na oposta. Resultados: Foi mostrado que a resistência à flexão não foi afetada pelo comprimento dos cp. Com a fotoativação em ambas as superfícies, as resistências obtidas eram semelhantes nos diversos comprimentos. Independentemente do número de faces irradiadas, os cp com $1 \mathrm{~mm}$ de altura apresentaram resistências semelhantes. Contudo, ср com $4 \mathrm{~mm}$ de altura e irradiados apenas por um lado, alcançaram os menores valores. Conclusão: Com o emprego de cp com dimensões menores são alcançados valores de resistência à flexão semelhante aos obtidos com cp padronizados (ISO 4049), com a vantagem de menor demanda de material e menor consumo de tempo (o menor comprimento dos cp requer apenas uma ativação por lado).

Unitermos: Resinas compostas; Resistência à flexão; Dimensões dos corpos-de-prova.
\end{abstract}




\section{INTRODUCTION}

Mechanical laboratory tests have been used in order to indirectly evaluate the degree of conversion of light-cured composite resins. Among several tests, the flexural strength is emphasized ${ }^{5,6,7,12}$, because it is strongly correlated with the fracture toughness test, which is supposedly able to predict the clinical performance of composite resins ${ }^{3}$.

The flexural strength of light-cured composite resins depends on their composition ${ }^{2,5,21}$ and mode of polymerization ${ }^{12,14,18}$. The less complete is the cure the lower is the flexural strength value. However, the increase in the exposure time of light-curing can compensate low light intensity ${ }^{13}$. A lower degree of conversion leads to a lower strength ${ }^{8,9,12,17,18}$, which occurs in depths far from the irradiated surface. In contrast, in depths minor than $1 \mathrm{~mm}$, strength is not affected ${ }^{4}$.

Although ISO 4049 Standard ${ }^{11}$ recommends a dimension of 25x2x2mm (length $\mathrm{x}$ width $\mathrm{x}$ height) for flexural strength tests and many authors have used them ${ }^{7,13,15}$, several other authors have also shown a great variability of these dimensions in their studies. The following dimensions were already described in the literature: $25 \times 5 \times 3^{5} ; 24 \times 1 \times 1^{3} ; 17 x 2 \times 2$ $\mathrm{mm}^{10}$. In 1991, Peutzfeldt and Asmussen ${ }^{20}$ used 10x2x2mm specimens and found higher flexural strength values than those previously reported in dental literature. This fact was attributed to the lower dimensions of the specimens. However, in posterior works ${ }^{2,21}$, they employed specimens with the same dimensions.

In spite of the great variability reported in other studies regarding specimen dimensions for 3-point flexural strength tests, no comparative study about the effect of them could be found, which was the main purpose of the present study. Light-curing and load application are as described on methods.

\section{MATERIALS AND METHODS}

The composite resin employed in this study was the Heliomolar RO (Vivadent - Schaan, Liechtenstein). Specimens were obtained from a split stainless steel matrix. The fitting between pieces of the matrix led to the acquirement of different sized moulds. The tested dimensions (length $\mathrm{x}$ width $\mathrm{x}$ height, in $\mathrm{mm}$ ) and the respective span (d) between the supports were: 25x2x4 and 25x2x2 (20); 15x2x2 (12); 10x2x2 and 10x2x1(8).

Specimens were light-cured on one surface or on both surfaces (as specified by the ISO 4049 Standard $^{11}$ ). When only one surface was irradiated, the fracture load was applied either on this side or on the opposite one. Therefore, considering 5 different specimen dimensions and 3 different associations of light-cure/surface of load application, the experimental design of this study consisted of 15 groups $(n=10)$ :

1. Light-cure on both surfaces and load application on any side (groups 1 to 5);

2. Light-cure on one surface and load application on the same side (groups 6 to 10);

3. Light-cure on one surface and load application on the opposite side (groups 11 to 15 ).

The composite resin was placed in one increment into the split stainless steel mould to make the specimens; the surfaces were covered with mylar matrix and glass slabs. Then, the set was clamped with a load of $8 \mathrm{kgf}$ for $5 \mathrm{~s}$ in order to allow removal of excess of material. An Optilux 401 device (Demetron Research Corp., Danburry, CT, USA) with output of $600 \mathrm{~mW} / \mathrm{cm}^{2}$ and a $13 \mathrm{~mm}$ wand straight light guide was used. Exposure time intervals of 40s were used in each site, throughout the study, according to the specimen length. In $25 \mathrm{~mm}$ long specimens, the light was first applied at the center of the surface, being both ends cured one at time (120s per surface). Light-curing of the $15-\mathrm{mm}$ long specimens was performed in two halves one at time (80s per surface). Finally, each surface of the $10 \mathrm{~mm}$ long specimen was light-cured for 40s at once, since their length was smaller than the diameter of the light tip source.

Following the light-curing, specimens were stored in distilled water at $37^{\circ} \mathrm{C}$ for $24 \mathrm{~h}$ in suitable storage containers, free of any sort of illumination, prior to testing. A special device was developed in order to test the specimens with different lengths. The apparatus consisted of adjustable blocks attached to the testing machine fixed base, which established the corresponding span between supports for each group to be tested. The test was performed in an INSTRON 4042 universal testing machine (Instron, Corporation, Canton, MA, USA) at a crosshead speed of $0.5 \mathrm{~mm} / \mathrm{min}$. The flexural strength of the specimens was calculated according to the following equation: $\mathrm{R}_{\mathrm{f}}=3 \mathrm{LF} /$ $2 b^{2}$, where $R_{f}$ is the flexural strength; $L$ is the span length; $\mathrm{F}$ is the load at fracture; $\mathrm{b}$ is the specimen width and $\mathrm{h}$ is the height of the specimen. The flexural strength values were expressed in MPa.

The data from the 15 groups were analyzed by means of one-way ANOVA. Tukey's test was used to determine statistical differences among means.

\section{RESULTS}

Results of ANOVA showed significant differences ( $p<0.001)$ among means. Table 1 presents mean values and standard deviation of the 15 groups.

The fracture strength mean values ( $\mathrm{MPa}$ ) obtained in groups 1 to 5 (specimens irradiated on both surfaces) varied from 91.9 to 97.1 and there were no statistically differences. This fact means that the specimen dimensions did not influence the flexural strength for these groups. In groups 6 to 10 (irradiated only on one surface with load application at the same one), 4-mm high specimens exhibited lower flexural strength compared to the groups 1 to 5 . The groups 11 to 15 (irradiated on one surface with the load application on the opposite one) revealed similar means as those obtained in groups 6 to 10 . However, the height of $4 \mathrm{~mm}$ showed the lowest strength, which was significantly different from the strength obtained with 1-mm high specimens. 
The groups 5, 10 and 15 (specimens 1mm thick) showed similar flexural strength values.

\section{DISCUSSION}

The length of the specimens (25mm) recommended by ISO 4049 Standard ${ }^{11}$ exhibits three major drawbacks: 1) a great expense of material; 2) the need of irradiation at three different sites of the specimen (center and both ends) per surface, and 3) it is a time consuming procedure.

The results of this study have shown that with lightcuring on both surfaces the flexural strength was not influenced neither by the length nor the height of the specimens. This may be due to more intense irradiation in depth. However, in the groups irradiated only on one surface, the different lengths also did not influence the results, since the differences found were due to the height of the specimen and not the lengths. The obtained values are similar to that found by Ferracane and Mitchen ${ }^{6}$ in a given site, when testing the same material.

The lowest flexural strength mean was found in 4-mm high specimens, light-cured only on one side. This fact can be attributed to a lower degree of conversion at the opposite side of the light-curing procedure ${ }^{1,8,9,12,16,17,18,19}$. The flexural strength of 1-mm high specimens exhibited similar means (groups 5, 10 and 15), which were also similar to the means obtained with specimens with the dimensions recommended by ISO 4049 Standard ${ }^{11}$. This fact showed that the reduction of the specimen dimensions did not influence the flexural strength values. Thinner specimens reduced the need of light-curing on both surfaces. These results are in agreement with the findings of Eliades, et al. ${ }^{4}$ According to these authors, the opposite surface of thinner specimens can be adequately light-cured, obtaining a higher degree of polymerization compared to thicker specimens.

A general analysis of the results showed that specimens with smaller dimensions than those standardized by ISO 4049 Standard ${ }^{11}$ led to similar flexural strength values. Besides that, smaller specimens (10 mm long) demand less material and allow a single light-curing in each surface with a height of $2 \mathrm{~mm}$, and needs only unique light-curing of specimens with a height of $1 \mathrm{~mm}$, contrary to six or three activations in 25-mm specimens. Moreover, the volume of composite resin used to prepare 10x2x2xmm and 10x2x1mm specimens are respectively 40 and $20 \%$ of those specimens with recommended dimensions proposed by ISO 4049 Standard $^{11}$ (25x2x2mm). Thus the use of shorter and thinner specimens results in less time and material consuming for future investigations.

\section{CONCLUSIONS}

Considering the results of this investigation, the following conclusions may be drawn:

1. Length of composite resin specimens for flexural strength does not influence the results. Lower values were obtained with 2 and specially $4 \mathrm{~mm}$ height specimens when only on one surface was light-cured.

2. Specimens of $10 x 2 x 1 m m$ (length $x$ width $x$ height), even when light-cured only on one surface, showed a flexural strength close to that obtained with ISO 4049 Standard.

TABLE 1- Flexural strength means and standard deviations (MPa)

\begin{tabular}{|c|c|c|c|}
\hline $\begin{array}{l}\text { Light-curing and } \\
\text { load application }\end{array}$ & $\begin{array}{l}\text { Specimen dimension, } \\
\text { length } x \text { width } \times \text { height }(\mathrm{mm})\end{array}$ & Group & $\begin{array}{c}\text { Means and standard } \\
\text { deviations and comparisons* }\end{array}$ \\
\hline Light-curing on 2 & $25 \times 2 \times 4$ & 1 & $91.9(07.2)^{\mathrm{abc}}$ \\
\hline surfaces and load & $25 \times 2 \times 2$ & 2 & $92.3(05.9)^{a b c}$ \\
\hline \multirow[t]{3}{*}{ application on any one } & $15 \times 2 \times 2$ & 3 & $97.0(07.6)^{\mathrm{a}}$ \\
\hline & $10 \times 2 \times 2$ & 4 & $97.1(09.5)^{\mathrm{a}}$ \\
\hline & $10 \times 2 \times 1$ & 5 & $95.1(08.3)^{a b c}$ \\
\hline Light-curing on 1 & $25 \times 2 \times 4$ & 6 & $78.6(12.0)^{\mathrm{de}}$ \\
\hline surface and load & $25 \times 2 \times 2$ & 7 & $96.2(08.6)^{a b}$ \\
\hline application on the & $15 \times 2 \times 2$ & 8 & $88.1(07.7)^{\mathrm{abcd}}$ \\
\hline \multirow[t]{2}{*}{ same one } & $10 \times 2 \times 2$ & 9 & $88.5(08.3)^{\mathrm{abcd}}$ \\
\hline & $10 \times 2 \times 1$ & 10 & $90.3(08.4)^{\mathrm{abcd}}$ \\
\hline Light-curing on 1 & $25 \times 2 \times 4$ & 11 & $71.8(12.5)^{\mathrm{e}}$ \\
\hline surface and load & $25 \times 2 \times 2$ & 12 & $84.5(08.2)^{\text {abcde }}$ \\
\hline application on the & $15 \times 2 \times 2$ & 13 & $83.7(08.7)^{\mathrm{bcde}}$ \\
\hline \multirow[t]{2}{*}{ opposite one } & $10 \times 2 \times 2$ & 14 & $82.8(07.2)^{\mathrm{cde}}$ \\
\hline & $10 \times 2 \times 1$ & 15 & $91.4(05.0)^{\mathrm{abcd}}$ \\
\hline
\end{tabular}

* Means with the same superscript letters are statistically similar $(p>0.05)$. 


\section{REFERENCES}

1- Asmussen E, Peutzfeld A. Flexural strength and modulus of a stepcured resin composite. Acta Odontol Scand. 2004;62:87-90.

2- Asmussen E, Peutzfeld A. Influence of UEDMA, BisGMA and TEGDMA on selected mechanical properties of experimental resin composites. Dent Mater. 1998;14:51-6.

3- Bird SE, Thompson JY, Bayne SC, Rapp MM, Stamatiades PJ, Berg JH. Mechanical properties of posterior composite materials [abstract 778]. J Dent Res. 1998;77:203.

4- Eliades GC, Vougiouklakis GJ, Caputto AA. Degree of double bond conversion in light-cured composites. Dent Mater. 1987;3:19-25.

5- Ferracane JL, Greener EH. The effect of resin formulation on the degree of conversion mechanical properties of dental restorative resins. J Biomed Mater Res. 1986;20:121-31.

6- Ferracane JL, Mitchem JC. Properties of posterior composites: results of round robin testing for a specification. Dent Mater. $1994 ; 10: 92-9$

7- Gregory WA, Berry S, Duke E, Dennison JB. Physical properties and repair bond strength of direct and indirect composite resins. J Prosthet Dent. 1992;68:406-11.

8- Hansen EK, Asmussen E. Visible-light curing units: correlation between depth of cure and distance between exit window and resin surface. Acta Odontol Scand. 1997;55:162-6.

9- Hirabayashi S, Hood JAA, Hirasawa T. The extent of polymerization of class II light-cured composite resin restorations. Effect of incremental placement technique, exposure time and heating for resin inlays. Dent Mater J. 1993;12:159-70.

10- Huysmans MCDNJM, Van der Varst PGT, Lautenschlager EP, Monaghan P. The influence of simulated clinical handling on the flexural strength and compressive strength of posterior composite restorative materials. Dent Mater. 1996;12:116-20.

11- International Organization for Standardization Dentistry - Resinbased filling materials. Switzerland: ISO; 1988. 11p. (ISO 4049: 1988).

12- Li J, Nicander I, Von Beetzen M, Sundstrom F. Influence of paste temperature at curing on conversion rate and bending strength of light-cured dental composites. J Oral Rehabil. 1996;23:298-301.

13- Miyazaki M, Oshida Y, Moore BK, Onose H. Effect of light exposure on fracture toughness and flexural strength of light-cured composites. Dent Mater. 1996;12:328-32.

14- Munksgaard EC, Peutzfeld A, Asmussen E. Elution of TEGDMA and BisGMA from a resin and a resin composite cured with halogen or plasma light. Eur J Oral Sci 2000;108:341-5.

15- Oysaed H, Ruyter IE. Composite for use in posterior teeth: mechanical properties tested under dry and wet conditions. J Biomed Mater Res. 1986;20:261-71.

16- Palin WM, Fleming GJ, Burke FJ, Marquis PM, Randall RC. Monomer conversion versus flexural strength of a novel dental composite. J Dent 2003;31:341-51.

17- Park SH. Comparison of degree of conversion for light-cured and additionally heat-cured composites. J Prosthet Dent.1996; 76:613-8

18- Park SH, Lee CS. The difference in degree of conversion between light-cured and additional heat-cured composites. Oper Dent. 1996;21:213-7.
19- Peutzfeldt A, Asmussen E. The effect of postcuring on quantity of remaining double bonds, mechanical properties and in vitro wear of two resin composites. J Dent. 2000;28:447-52.

20- Peutzfeld A, Asmussen E. Mechanical properties of the composites resins for the inlay/onlay technique. J Prosthet Dent. 1991;66:322-4.

21- Peutzfeld A, Sahafi A, Asmussen E. Characterization of resin composites polymerized with plasma arc curing units. Dent Mater. 2000;16:330-6. 